\title{
Dom narożny w kwartale zabudowy miejskiej - znak miejsca albo ku formie predestynowanej do oryginalności
}

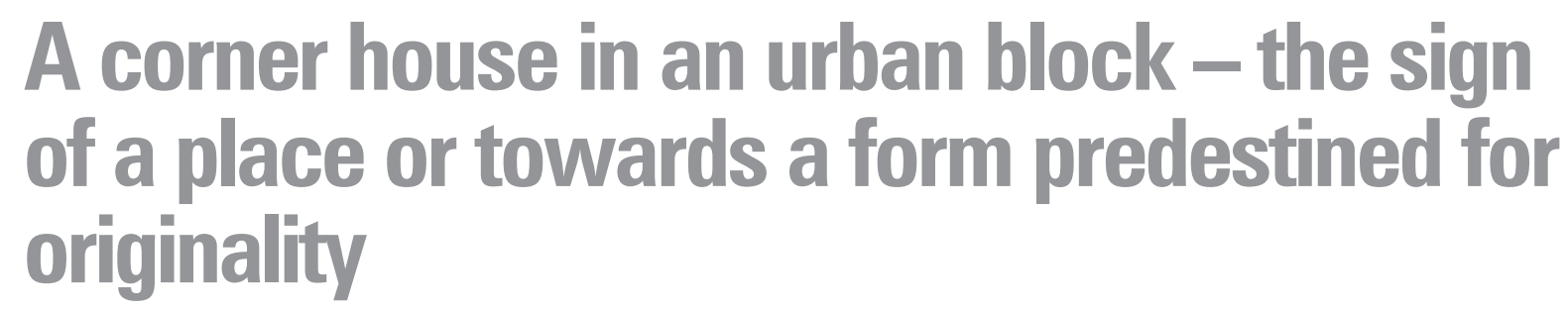

\begin{abstract}
Streszczenie
Tematem artykułu są domy narożne w kwartale zabudowy miejskiej i towarzysząca im wyjątkowość formy wynikająca ze specyfiki ich usytuowania w strukturze miasta. Celem badań jest wykazanie, iż znane z przeszłości rozwiązania próbują być współcześnie implementowane i reinterpretowane na nowych warunkach formalnych i estetycznych. Badania zostały przeprowadzone ze względu na wyjątkową specyfikę przestrzenną formy domu narożnego w zabudowie miejskiej, która jest predestynowana do rozwiązań oryginalnych i od zawsze stanowiła twórczą pokusę do wymyślania kształtów mogących aspirować do miana lokalnego znaku miejsca. Przedmiotem badań są budynki narożne o szeroko rozumianym przeznaczeniu mieszkalnym, których formy mają kluczowy wpływ na rozpoznawalność współtworzonych miejsc. Podstawową metodą badawczą jest analiza wybranych realizacji. Wyniki badań wskazują na różnorodne rozstrzygnięcia przestrzenne brył domów narożnych, dając przesłanki do wypracowania pewnych typologii i teoretycznych podstaw projektowania tego rodzaju zabudowy. Na podstawie przeprowadzonych badań wysunięto wnioski dotyczące zasad komponowania atrakcyjnych form domów narożnych. Atrakcyjność ta może być realizowana zarówno w oparciu o rozwiązania zachowawcze i wynikowe, jak i tworzyć czytelny znak miejsca poprzez oryginalne formy, często o ekspresywnym charakterze.
\end{abstract}

\begin{abstract}
The topic of the paper are corner houses in an urban block and the accompanying uniqueness of form that results from the specific nature of their location in the urban structure. The study aims to demonstrate that there are currently attempts at implementation and reinterpretation of the solutions known from the past under new formal and aesthetic conditions. The study was conducted owing to the unique spatial specificity of the form of a corner house in urban development, which is predestined for original solutions and has always been a creative temptation to invent shapes that can aspire to the status of the local sign of a place. The subject of the study is corner buildings with a broadly understood residential purpose whose forms have a key impact on the recognition of co-created places. The basic research method is the analysis of selected developments. The research results indicate various spatial solutions of the bodies of corner houses, giving premises for the formulation of certain typologies and theoretical bases for the design of this type of buildings. On the basis of the research, conclusions were drawn on the principles of composing attractive forms of corner houses. This attractiveness can be achieved both by means of conservative and resultant solutions, as well as by creating the legible sign of a place through original forms which are frequently expressive in character.
\end{abstract}

Słowa kluczowe: dom narożny, sytuacja narożnikowa, znak miejsca

Keywords: corner house, corner situation, sign of a place

\section{Wprowadzenie}

Forma domu narożnego w kwartale zabudowy miejskiej jest predestynowana do oryginalności ze względu na wyjątkowe miejsce, jakie zajmuje w strukturze miasta. Powstając u zbiegu ulic, współtworzy wizualnie istotne elementy wnętrz urbanistycznych, które niejednokrotnie definiują początek przestrzeni miejskiej. Bryła domu narożnego, zaprojektowana w odpowiednio wyrazisty sposób, często przybiera postać znaku miejsca, orientującego przechodnia na określone kierunki komunikacyjne w zwartej tkance zabudowy. Tomasz Kozłowski, pisząc - Tendencjach ekspresjonistycznych w architekturze współczesnej, wspomina o "sytuacji narożnikowej”, podkreślając jej szczególną rolę, polegającą na „zwolnie-

\section{Introduction}

The form of a corner house in an urban block is predestined for originality due to its unique place in the urban structure. Being created at the intersection of streets, it visually co-creates important elements of urban interiors that often define the beginning of urban space. The body of a corner house, designed in a properly distinctive way, often takes the form of the sign of a place, orienting the passer-by towards specific communication directions in a compact building tissue. When writing about Expressionist Tendencies in Contemporary Architecture, Tomasz Kozłowski mentions the "corner situation", emphasizing its 
niu architekta od badania motywacji urbanistycznych". "Sytuacje narożinowa" zdefiniowano tu, jako "teren wyznaczony ulicami zbiegającymi się pod kątem (najlepiej ostrym), wskazującymi linie zabudowy". Towarzyszy temu spostrzezenie, że: „Architektura w takim miejsc zyskuje ekspresję bez dodatkowych zabiegów, a starania tworcy, by nadac formie ekspresjonistyczny wyraz są wspierane przez sytuacje przestrzenną", co dowiedziono licznymi przykładami'. Dom narożny w kwartal zabudowy miejskiej jest uprzywilejowany przestrzennie ze względu na sytuację urbanistyczną, która determinuje potrzebę oryginalności jego formy. Ten rodzaj uprzy wilejowanej ekspozycji w strukturze miejskiej pozwala budynkom uzyskiwac status architektonicznego znaku czy kony, decydujace o istoln an elemencie tożsamości tacińskim terminem genius loci. Sytuaja na rożikowa jest zarazem wdziecznym, jak i wymaga naroznkowa architektonicznym. Daiac moiliwość wykazania sie tolentem twórczym, pozwala architektom na eksperymentowanie z forma co uzasadnia czy wrecz usprawiedliwia przestrzenną potrzebę jej oryginalności.

2. Główne zagadnienia typologiczne kształtowania formy domu narożnego w kwartale zabudowy miejskiej

\subsection{Kryterium kąta}

Za element wylsciowy typologii domu narożnego w zabudowie miejskiej należy uznać specyfikę planu budynku, wynikającą z charakteru sytuacji narożnikowej, a do- exceptional role of "exempting the architect from the tion" is defined here as "the area delineated by streets converging at a (preferably acute) angle, indicating the lines of development". It is accompanied by the obsevation that: "Architecture in such a place gains expression without any additional efforts, and the artist's endeavours to give the form an expressive character are supported by the spatial situation", as has been proved by numerous examples ${ }^{1}$. The corner house in the urban block is spatially privileged due to the urban situation that determines the need for originality of its form. This type of privileged exposure in the urbar is form. This tys buildings to acquire the status of the arditecallows billing the ign icon, deterning the essential element of the identy of the place and its indeffable "climate", referred to with the Lath term genins loci. The comer siculion is both a graceful and demanding architectura task. Giving the opportunity to manifest creative talen, it allows architects to experinen with form, which justifies or even excuses the spatial need for its originality.

2. Main typological issues of shaping the form of a corner house in the urban block

2.1. The angle criterion

The starting point for the typology of a corner house in urban development should be the specificity of kładniej wskazać tu należy na kąt, pod jakim zbiegaja zeniu obu pierzei. Wyroźnic możeny trzy podstawowe typy domow narożnych, ktorych plan jest determinowany kątem wyznaczonym przez linie zabudowy u zbiegu dwóch ulic. Mowimy tu o budynku narożnym rozwartokątnym, prostokątnym lub ostrokątnym (il. 1). Ów kąt ma zasadnicze znaczenie dla ksztattowania formy oraz funkcji takiego obiektu. Domy narożne wznoszone na plani kąta rozwartego cechuje najmniejszy do uzyskania dynamizm formy w ujecciu perspektywicznym. Jest za to zazwyczaj najbardziej korzystny pod względem sposobu doswietlenia pomieszczen. Poprawnie można rozplanowac tu takze funkcje mieszkaln. Naroźniki na planie jea prostego pozwaląa na zyna nizowarie formy, przy

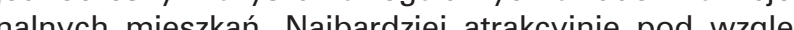

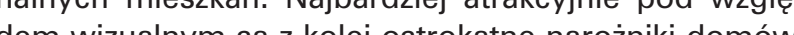
To one determinuja w naimiekszym stopniu dynamizm, oraz ekspresyjny wyraz bryły budynku. Tego typu sytudcja narożna predestynuje przestrzennie forme do oryginalności usprawiedliwiając niejednokrotnie twórcze poszukiwania i kompozycyine eksperymenty architektów. Racjonalność i poprawność funkcjonalna rozplanowania pomieszczeń mieszkalnych, jak i całościowego układu przestrzennego w tego typu budynkach jest zazwycza ograniczona i czesto trudna do osiagnięcia. Można przyjać ogólne prawidło mówiące, że im kąt narożnika budynku jest ostrzejszy tym forma jest bardziej dynamiczna i atrakcyjniejsza dla oka, lecz ten ekspresywny wyraz the plan of the building resulting from the character of the corner situation, and more precisely the angle at which the main planes of the front elevations converge on the extension of both frontages. We can distinguish three basic types of corner houses whose plan is determined by the angle designated by the lines of development at the junction of two streets. We refer here to a corner building that is obtuse-angled, right-angled or acute-angled (Fig 1 ). This angle is essential for shaping the form and funcThis ang is essentiar. Corner houses erected on dynamic form in terms of perspective. However, is usully the most advaf pesective. However, it ighting of roms. It is also possibe to adeque plan the rous. $t$ is also possible to adequately on a rightadted pun allow to dy Con structures while simangled plan allow to dy namize the form, Whe sim visually attractive are the acute-angled corner houses. They determive expressive character of the bulling to the greatest extent. This type of corner stuation spatially predestines the form to originality often justifying the architects' creative search and compositional experiments. The rationality and functional correctness of the layout of living quarters and of the entire spatial arrangement of such buildings is usually limited and often difficult to achieve. The

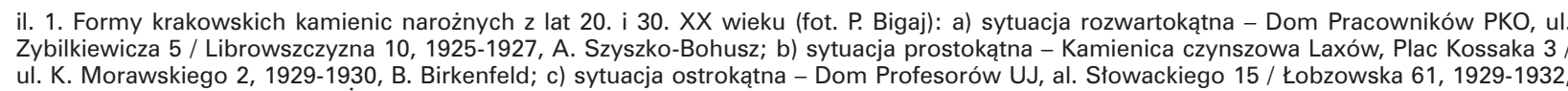

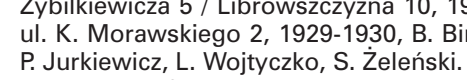

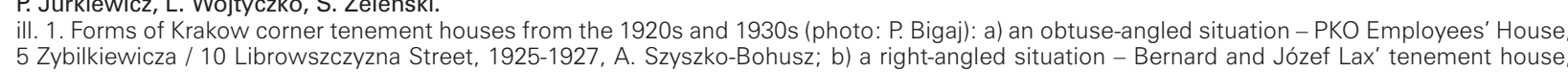

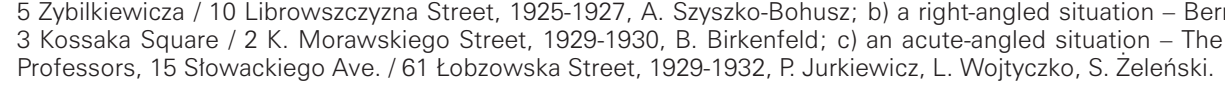

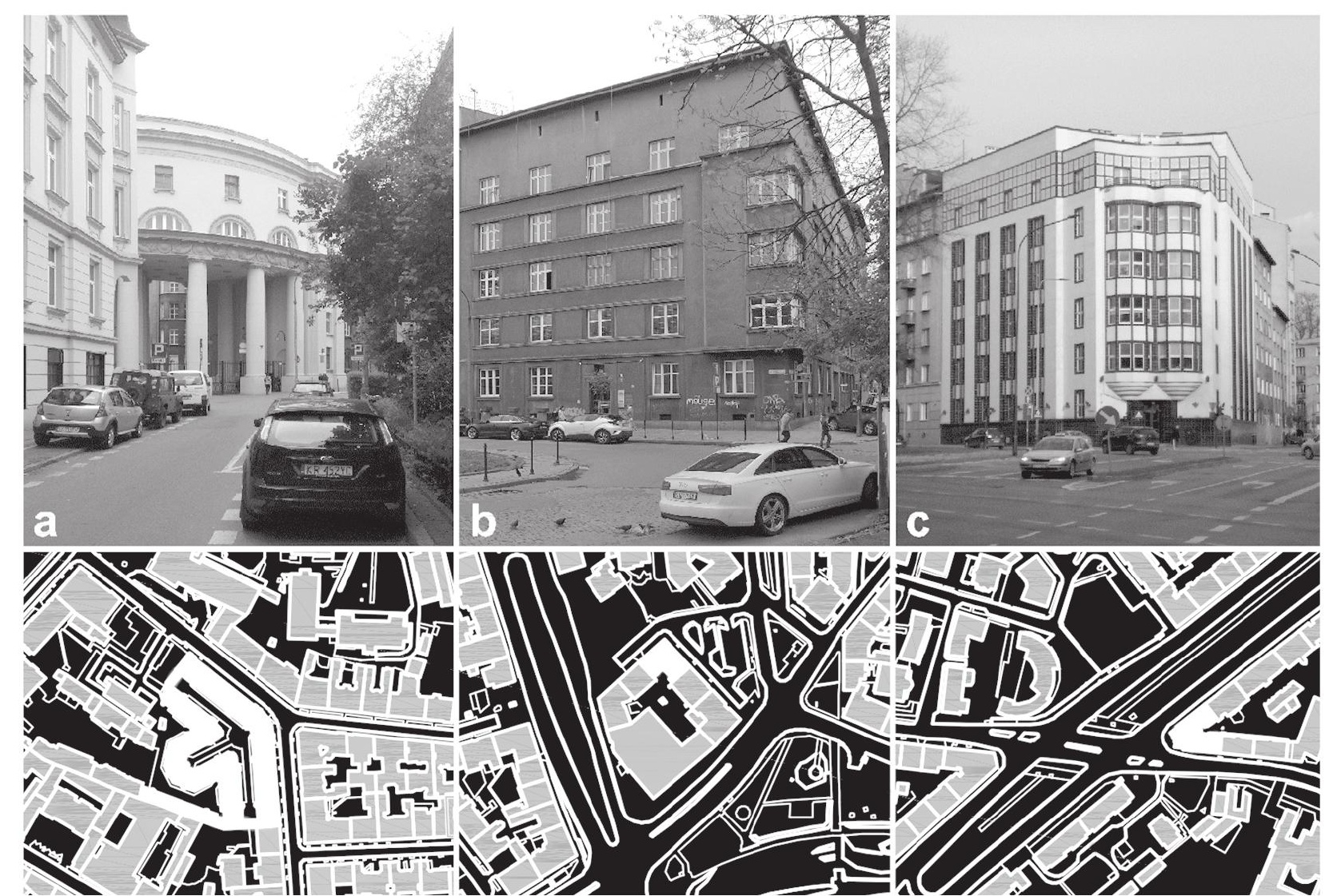

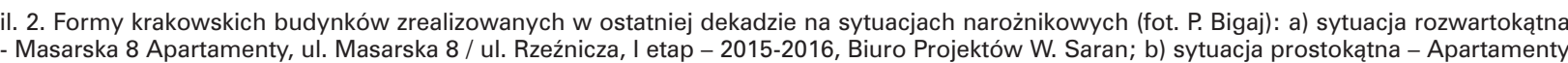

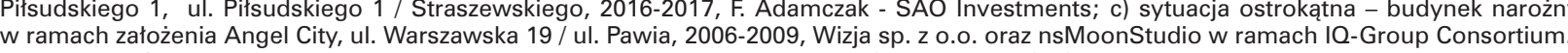

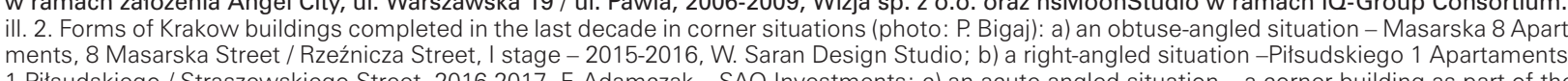

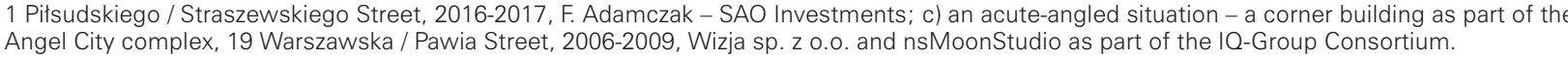

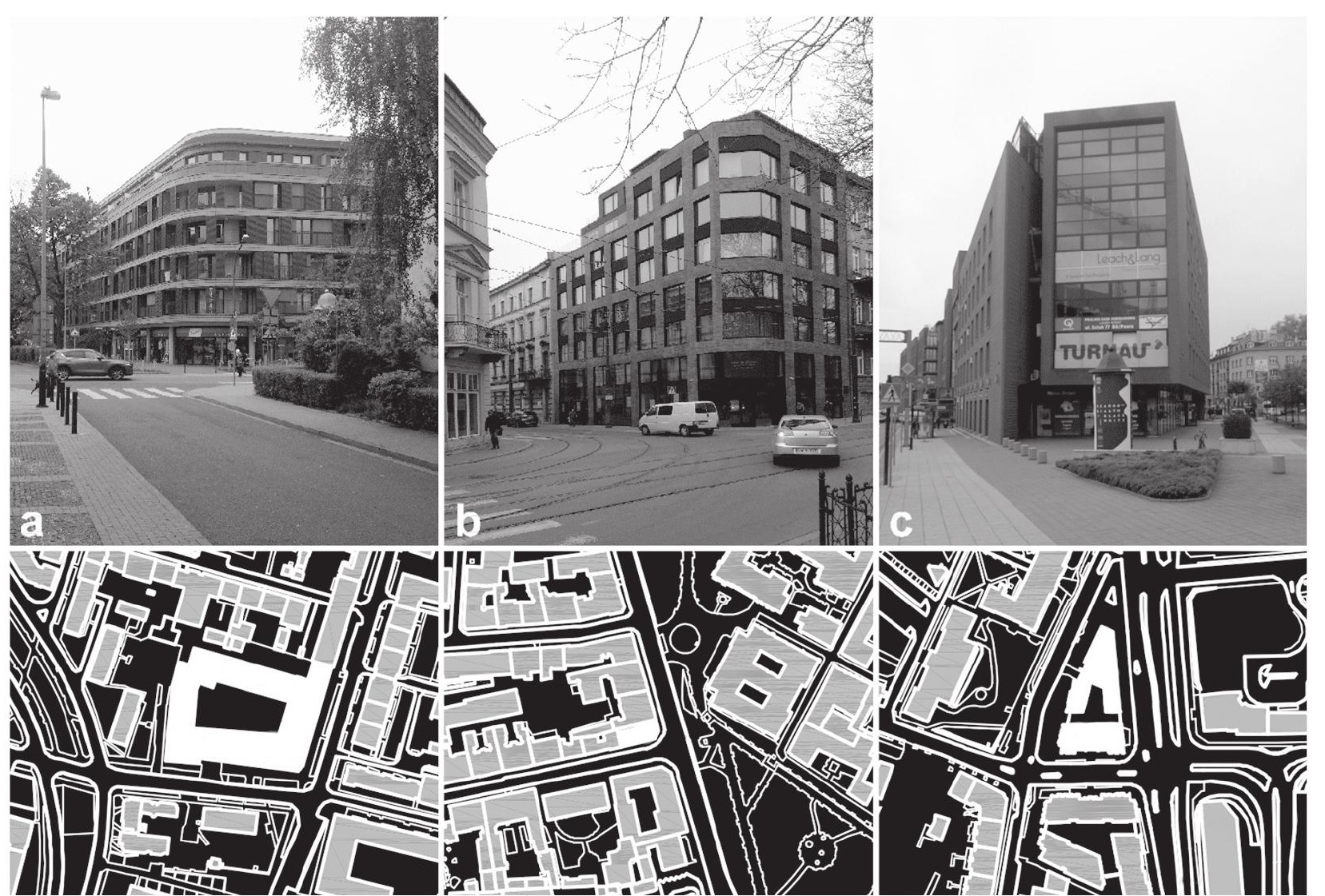


budynku. Za część narożnikową zazwyczaj uznajemy część wspólną, przynależną do obu ramion takiego budynku, które zbiegają się pod określonym kạtem na przedfuzeniu pierzei dwoch ulic. Nie jest to ścisła reguła, lecz najczęściej w tej wspólnej strefie przenikania się ramion budynku kształtowana jest przez architektow forma wizualnie odczytywana jako narożnik. Naroże budynku od zawsze stanowiło pole do eksperymentowania z bryłą o wyróżniającym się statusie przestrzennym, stąd pojawiały sie tu takie formy architektonicznie akcentujące, jak wykusze, balkony loggie, itp. Oprócz form akcentujących, częstą praktyka sa formy narożne zwieńczone wieżyczkami czy sygnaturkami pełniącymi w skali zwartych przestrzeni miejskich rolę lokalnych subdominant i dominant. było takze niewyróżnianie w jakiś szczególny spoś nyoziniza, który w tym przypadku przybierat zazwyczaj forme wynikajaca wprost z układu urbanistycznego tkanki miejskiej. Przyjmujac kryteria urbanistyczne, majace wptyw na tworzenie jakości i charakteru przestrzeni miejskich, można przyjać ogólna klasyfikacje typologiczna budynków narożnych na te: z elementami akcentujacymi naroże (np. wykusz, balkon, loggia, attyka narożna), czy z elementami subdominan i dominant $w$ narożniku (wieżyczka, podwyższenie dodatkowe piętro części narożnikowej) i tzw. „narożnik wynikowy", ti. bez specjalnego wyróżnienia formy narożnika. Aspekt oryginalności jest tu ściśle powiązany z kontekstem miejsca i wymaga pomystowości od architekta na wykorzystanie tej sytuacji do stworzenia lokalnego znaku miejsca. To, że budynki narożne i ich architektoniczne uformowanie odgrywa szczególne znaczenie urbanistyczne $w$ tradycyjnie kształtowanych tkankach miejskich, widoczne jest choćby w postmodernistycznej twórczosci Roba Kriera ${ }^{3}$ czy zwolennik tradycjonalizmu - Leona Kriera ${ }^{4}$.

\subsection{Kształt naroża}

Decyzje projektowe związane z kształtem narożnika sa podejmowane nie tylko ze względów czysto estetycz nych, ale także ze względu na komunikacyjny charakte i potrzebę zapewnienia odpowiednich parametrów użytecznych dla sytuacji węzłowej u zbiegu ulic. Michał Domińczak i Artur Zaguła wyróżniaja pod tym względem trzy podstawowe typy kamienic: z prostym, zaokra-

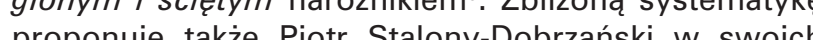
brodanich nad opracowywanym Albumem domów naroznych miasta Krakowa. Wymieniono tu takie ot warty kształt narożika, jako jeden ze sposobów komponowania formy budynku dla sytuacii narożikowe poprzez cofniecie lub pustke 6 . Wzgledy urbanistyczn i komunikacyine nie sa jedyna konsekwencja poszukiwania właściwej formy dla narożnika. Determinanta twórczych poszukiwań staje się też potrzeba poprawnego rozplanowania funkcji w części narożnikowej. Jak podkreśla Zuzanna Borycz „w przypadku skrzyżowania ulic pod ostrym kątem budynki narożne nie mają ekonomicznych rzutów, pomieszczenia narożne są nieustawne i wąskie. Ażeby uniknąć takich sytuacji, zabu- more predestined to originality, due to the departure riods of historicism, so widespread in the past that they give the impression of being "naturally" justified for corner situations.

2.3. Typology due to the urban significance of the space - accent subdomint, domint, resulting corner

The key element of the architectural composition of the houses described here is the so-called corner part of the building. We usually consider the corner part to be the common part, belonging to both arm of such a building that converge at a certain angle on the extension of the frontage of two streets. This is not a strict rule but the form visually interpreted as a corner is shaped by architects most often in this commo zone at the intersection of the arms of the building.

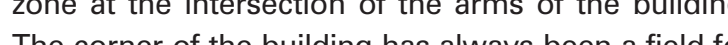
experimenting with a experimenting with a body with a distinctive spatia status, hence such architecturally accentuating forms as bays, balconies, loggias, etc. have appeared here. Apart from accentuating forms, corner forms topped with turrets or fleches, which play the role of loca sub-dominants and dominants on the scale of compact urban spaces, are common practice. Another form, especially in more modest buildings, was that of not distinguishing the corner in any particular way, which in this case usually took on a form resulting directly from the urban layout of the urban tissue. When adopting urban criteria affecting the creation of quality and character of urban spaces, a general typological classification of corner buildings may be adopted: those with elements emphasizing the corner (e.g. bay window, balcony, loggia, corner attic), or with subdominant and dominant elements in the corner (turret, elevation additionat floor of the corner pert) and the eso the without speci is closely linked to the context of a pect of originality is closely linked the conext of a place and requires the ingenty of hise archiect to use this sifulion to create the local sign of a place. The fact that corne buildings and their architectural formation play a special urban role in the traditionally shaped urban tissues is reflected in the postmodern work of Rob $\mathrm{Krier}^{3}$ or the supporter of traditionalism - Leon $\mathrm{Krier}^{4}$.

\subsection{The shape of a corner}

Design decisions related to the shape of a corne are made not only for purely aesthetic reasons, but also due to the communication character and the need to ensure appropriate parameters that are useful for the junction situation at the intersection of streets. Michał Domińczak and Artur Zaguła distinguish three basic types of tenement houses in this respect: with a straight, rounded and truncated corner ${ }^{5}$. Similar systematics is also proposed by Piotr dowa najczęściej nie dochodzi do naroża, działka jest zaokraglona lub scinana do uzyskania szerokosci około $20 \mathrm{~m}^{\prime \prime}$. Narożnik jest tu centra pozycji, kumulującym w tej częsci budynku ów efekt oryginalności, który przyciąga uwagę przechodnia oraz wskazuje na sytuacje komunikacyjnie ważne w przestrzeni miejskiej. Narożnikowy „znak miejsca” kształtowany poprzez formy proste, obłe, ścięte, czy też przez zabawę $w$ cofnięcie, pustkę lub otwarcie jest nieodzow nym elementem języka urbanistycznego zwartej tkank miasta. Obfituje on dodatkowo w akcenty, dominanty, subdominanty przesądzając o organizacyjnej roli tej ar-
chitektury na przestrzeń miejską.

\section{Dom narożny - wybrane przykłady}

Sośod licznie realizowanych budynków narożnych, 作 nazwa Ginger i Fred, który zostat zaprojektowany przez Franka Gehry'e siony w Pradze (Czechy, 1996) przykład dekonstruktywistycznej formy, która choć nazwana jest domem to mieści zróżnicowany program funkcjonalny. To co wyróżnia ten narożnik, to nie tylko zdynamizowany kształt, zróżnicowanie materiałów, ale i sam fakt, że budynek wychodzi poza wynikowa linie zabudowy podkreślajac jeszcze bardziej narożnikowość same sytuacji (il. 3). Innym przykładem z Pragi może być kamienica Františka Hodka z 1913 roku, zaprojektowana przez Josefa Chochola, która swoją rozpoznawalnośc zyskała nie tylko za sprawą ostrego kąta naroża, ale i dzięki charakterystycznemu stylowi tzw. „kryształowego" kubizmu. Mozna sięgnąc także do innego ikonicznego przykładu jakim jest zrealizowany w 1910

il. 5. L40, Linienstraße 40 / Rosa-Luxemburg Straße, Berlin, Niemcy,
2004. 2010, Bundschuh Architekten, (fot. W. Cieptucha).
ill. 5. L40, 40 Linienstraße it Rosa-Luxemburg Straße, Berlin, Germany,
2004-2010, Bundschuh Architekten, (photo W. Cieptucha).

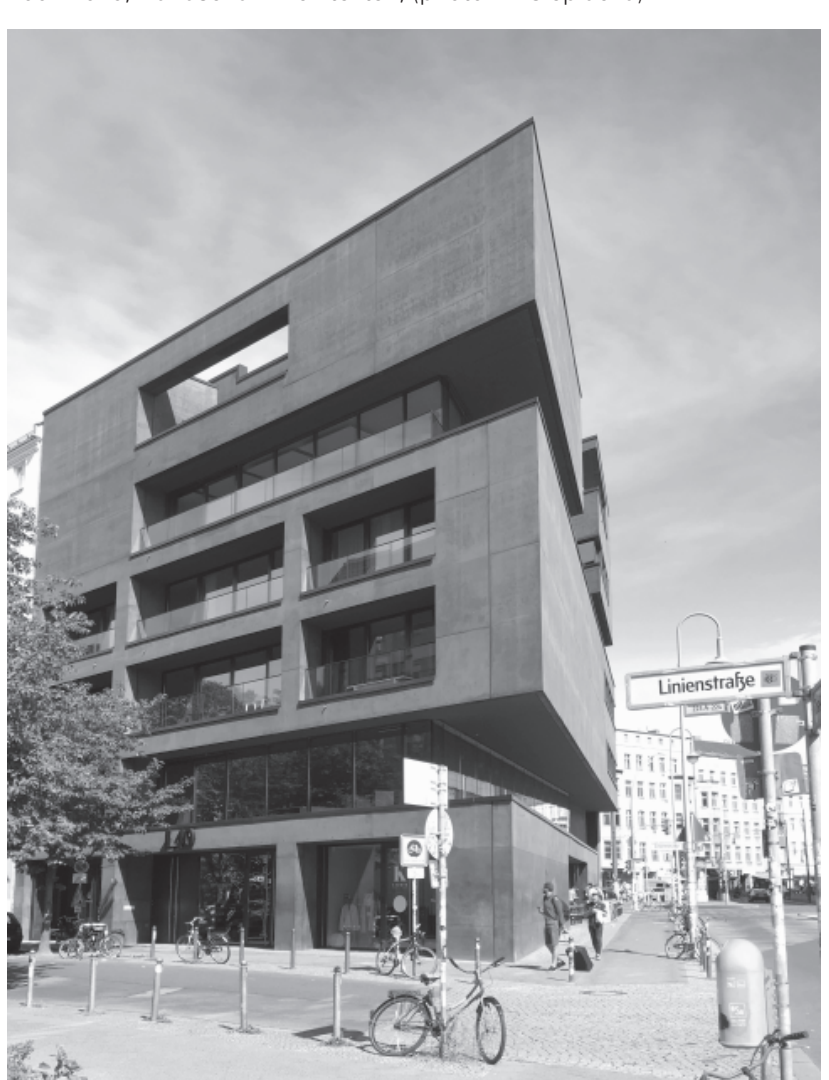

Stalony-Dobrzański in his study on the developed Album of Corner Houses in the City of Krakow. The open shape of a corner is also included here, as one of the ways of composing the form of a building for a corner situation by recession or void ${ }^{6}$. Urban and communication considerations are not the only consequence of the search for the appropriate form of the corner. The need to properly plan the function in the corner part also becomes a determinant of creative pursuit. As emphasized by Zuzanna Borycz, "in the case of sharp-angled street junctions, corner buildings do not have economic projections, the corner rooms a non-adjustable and narrow. In order situations, the building development do not usualy reach the comb bu buing rounded or cut to a widh of about $20 \mathrm{~m}^{\prime \prime}$. The cor ner is the cut to a width of about $20 \mathrm{~m}$. The corcumulates the lefect of originality in this pact ac building artatis bulding, atracting the attention of the passer-by and indicating the communication situations important The corner "sign of a place" shaped by simple, round, truncated forms, or by the game oid or opening-up is an indispensable the compact urban issue. It additionally abounds in accents, dominants, and subdominants, determining the organizational role of this architecture in the urban space. Among the numerous completed corner buildings, one of the most original examples is the Dancing House, also known as Ginger and Fred, designed by Frank Gehry and Vlado Milunić. Although it is called a "house", this example of a deconstructivist form built in Prague (Czech Republic, 1996) contains a varied functional programme. What distinguishes this corner structure is not only the dynamic shape and diversity of materials, but also the fact that the building goes beyond the resulting line of development, emphasizing even more the corner nature of the situation itself (Fig. 3). Another example from Prague is the František Hodek's tenement house from 1913, designed by Josef Chochol, which gained its recognition not only because of the acute-angled corner, but also owing to the characteristic style of the so-called "crystal" cubism. Another iconic example is the corner building Casa Mila, designed in Barcelona by Antonio Gaudi in 1910, where organic and rounded corrugations of the façade contribute to the unique architecture. In these cases, the originality of the architecture, the way the façades are formed and the characteristic detail allow to mark the urban space with recognizable buildings - icons. Referring to a few examples from Berlin, it can be shown that it is not only the originality of forms and their complexity that makes it possible to create architecture with the status of the so-called "sign of a place". Strongly 


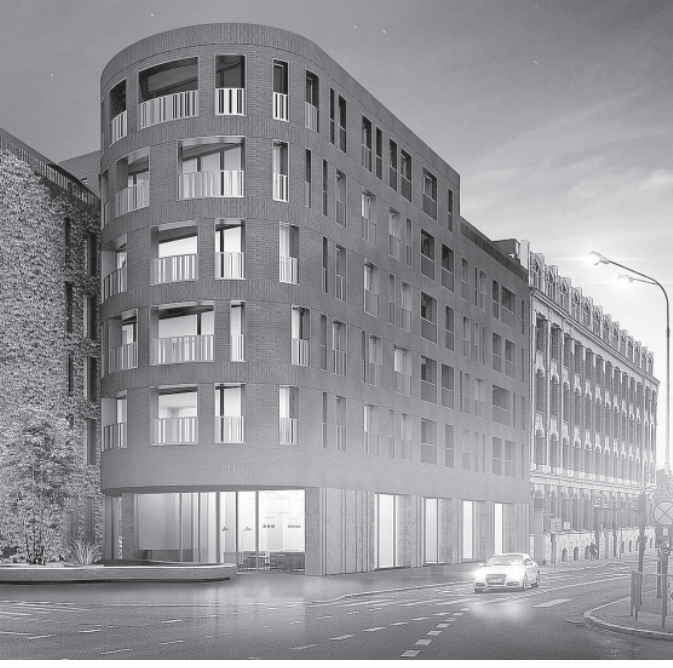

barceloński budynek narożny Casa Mila zaprojektowany przez Antonio Gaudiego, gdzie organiczne i obłe pofalowania elewacji decydują o wyjątkowej architekturze. W tych przypadkach oryginalność architektury i sposób uformowania fasad oraz charakterystyczny detal pozwala naznaczyć przestrzeń miejską rozpoznawalnymi budynkami - ikonami. Sięgając z kolei do kilku berlińskich przykładów, można wykazać, że nie tylko oryginalnosć form i ich złozonośc pozwal wworzyć architekturę o statusie tzw. „znaku miejsca“. Sprawdzają się tu silnie zgeometryzowane kształty brył domów narożnych, w których dostrzega się istot estetyki własciwą dla tendencji neoracjonalistycznych czy postmodernistycznych. Spoista forma z wyrazistą i konsekwentną artykulacją otworów okiennych, o lekko monumentalizującym wyrazie, silnie osadzona w kontekście miejskim i poszukująca w nowym detalu zastosowanym materiale dialogu z przeszłością, to podstawowe środki oddziaływania na widza tego rodzaju architektury. Wymienić tu można budynek przy przez Mario Botte (il. 4) jak i budynki autorsto Aly Rossiego no kamienica przy Kochstraße 1-4 i Wit hossiego, np. Kamienica przy Kochstraße 1-4 i WilBraghieri) czy Quartier Schützenstraße, który zosta zbudowany w latach 1994-1998. Tu prostokatne cztey naroża kwartalu zabudowy potraktowano nie tyl

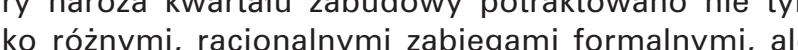
wyrazista kolorystyka fasad. Ich przeciwieństwem, zarazem intrygujacym dla oka przykładem jest zakrzywiony, o wyoblonym narożu dom Bonjour Tristesse na skrzyżowaniu Schlesische Strase i Falckensteinstrasse, który zaprojektowany został przez Alvaro Sizę i Petera Brinkerta (realizacja 1984). Szare, płynnie przechodzące fasady $z$ rytmicznie $i$ konsekwentnie rozliczonymi otworami okiennymi podkreślają krzywolinijny kształt narożnika. Osiągnięta $w$ ten sposób lapidarność ekspresji zadecydowała, iz budynek ten da się określić jako „znak miejsca”. Sięgając do realizacj $z$ ostatniej dekady można wymienic budynek narożny L40 (Bundschuh Architekten, 2010), przy Linienstraße il. 6. Przykład pracy konkursowej na kamienice narożna, skrzyżo-
wanie ulic Sienkiewicza i Orlej w todzzi, autorzy: P. Bigaji, P. Bronietódzka - edycja druga 2017; organizator konkursu: Miasto tó́c Departament Archite ktury R Rozwoju, Biluro Architekta Miasta. ment house intersection of Sienkiewiczicza and Orlei a Streets in tódz. authors: P. Bigaj, P. Broniewicz, P. Mika a - honourablete mention
Wspótczesna Kamienica tódzka - edycjaj druga a 017 (Contempo Wary Tenement House in Lódź- - second edition 2017); the organize
of the competition: The City of tódź, Department of Architecture
and Development, Office of the City A Architect.

geometrised shapes of the bodies of corner houses, in which the essence of aesthetics characteristic for neo-rationalistic or postmodern tendencies is noticed, are effective here. Their cohesive form with disinctive and consistent articulation of window openings, with a slightly monumental expression, strongly ins dialded in a dialded in the urb context and searching for the (B) One can (1900, designed by Mario Bota (Fig 4), as we from 1990, designed by Mario Botta (Fig. 4), as well as the buildings designed by Aldo Rossi, such as the (1980 helmstralße (1981-1988, cooperation: Gianni Bragheri) or the Quartier Schutzenstraßse, which was buit between 1994 and 1998. Here, the rectangular four corners of the urban block were treated not only with different rational formal procedures, but also with distinct colours of the façades. Their opposite and at the same time intriguing example is a curved house with a rounded corner Bonjour Tristesse at the crossroads of Schlesische Strase and Falckensteinstrasse designed by Alvaro Siza and Peter Brinkert (1984). The grey smoothly flowing façades with rhythmically and consistently arranged window openings emphasize the curved shape of the corner. The conciseness of expression achieved in this way contributed to the act that the building can be described as the "sign of a place". Among the developments from the last decade, the corner building L4O (Bundschuh Archicocade, the corner building $L 40$ (Bundschuh Archi-

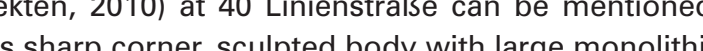
sharp corner, sculpted body with large monolithic planes also creates an aesthetically balanced arch ( (

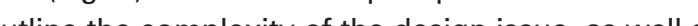

40. Jego ostry narożnik, rozrzeźbiona bryła z dużymi, monolitycznymi plaszczyznami również twozy zoną estetycznie architekturę „znaku miejsca”, której ekspresja wynika wprost z ostrokątnej sytuacji narożnikowej (il. 5). Przytoczone tu nieliczne przykłady zarysowują jedynie złożonosc problematyki projektowe jak i ogrom możliwosci przed jakimi staje twórca narożnego dzieła architektury.

4. Podsumowanie

Dom narożny w kwartale zabudowy miejskiej staje sie wdzięcznym tematem kursowym dla adeptów sztuki a chitektonicznej, bywa elementem prac warsztatowych, jest też ciekawym tematem studialnych konkursów architektonicznych (il. 6). Dzieje się tak ze względu n urbanistyczną predyspozycję sytuacji narożnikowej do tworzenia form oryginalnych, których atrakcyjność podkreślano odpowiednio zakomponowaną bryłą budynku. Już sama sytuacja narożnikowa prowokuje twórcę do zabawy w architekturę ekspresyjną i poszukiwania form aspirujących do miana "znaku miejsca". Niekoniecznie oryginalność czy złożoność kształtów może zapewnic wizualny sukces budynkowi narożnemu. Często umiejęt ne wpisanie się kubaturą w zastana sytuacje już wystar czy, aby osiaggnąc zadowalający efekt. Tomasz Kozłowsk pisze, iż: „Atrakcyjność sytuacji narożnikowej dla wspomozenia ekspresji formy architektonicznej dostrzeżono zanim uczynili to architekci modernizmu. Sama sytua cja nie tworzy ani nurtu, ani kierunku, czyni - przypadk niekiedy interesujące. (...) Samo połozenie budynku nie przesaadza o stosownej wyrazistości formy. Usytuowanie jednak bywalo wažnym pretekstem architektonicznym wykorzystywanym welokrotnie w przeszlości, w dzie-

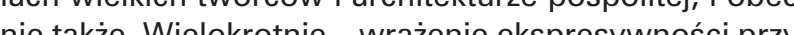
cokí.

Wórca, poszukując właściwej formy dla zastanej sytupozycyine,

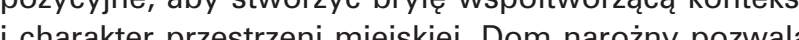
na poszukiwanie rozwiazán oryginalnych, awangardowych, o wyraźnej eksposi. Estetyka budyku nażwego, aby mogla aspirować do miana znaku miejsca

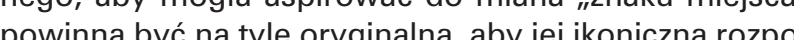
znawalność nie budzila watpliwóci. $Z$ trzech możliwy(a) sie być najbardziej predestynowana do tego zadania decyduie to jednak o tym, że sytuacja rozwartokatna czy prostokatna nie zapewnia tej możliwości, tylko że sytuacja ostrokatna w naturalny sposób wzmacnia dynamizm uecia perspektywicznego. Architekt inspiruiac sie dokonaniami przeszłości i czerpią z typologicznie dó horodnych sposobów kształtowania naroża budynku, jest w stanie osiagnać wystarczajace efekty estetyczne aby zapewnić budynkowi narożnemu status znaku, czy wreecz ikony miejsca. Oprócz wiedzy, niezbedne sa takż umiejejności i talent bez którego nawet najkorzystniejsza urbanistycznie sytuacja może obrócić sie przeciwko renomie zawodowej twórcy i przede wszystkim jakośc przestrzeni miasta. the enormous possibilities that the creator of a corner work of architecture faces.

4. Conclusion

A corner house in an urban block becomes a very attractive course subject for students of architectura art, it is sometimes an element of workshop works, and an interesting subject of study architectural competitions (Fig. 6). This is because of the urban predisposition of the corner situation to create origina forms, whose attractiveness has been emphasized by the appropriately composed body of the building. The corner situation itself provokes the creator to play a game of expressive architecture and search for forms aspiring to the name of the "sign of a place". It is not necessarily the originality or complexity of shapes that can ensure the visua success uilding. It is often enough to skilfully em bed the body of the buiding into the existing situaben in or to achieve a Kozlowsiv wites that: "The atractivess of the corKozilowsk wites the "The atrociven of the cortering by the morn had been noticed before it was done by cas of cer the buidung itself does not determine the relevant ss of the form. The location, however, was an important architectural pretext used frequently in the past, in the works of great artists and in . the impression of expressiveness comes by itself Looking for the appropriate form for the existing corner situation, the creator can use various compositional techniques to create a body of the building that contributes to the context and character of urban space. The corner house allows for the search for original, avant-garde solutions with distinct expression. To aspire to the name of the "sign of a place" the aesthetics of the corner building should be orignal enough to make its iconic recognition unmistakabe. Of the three possible cases, it is the acute-angled corner situation that seems to be the most predesthe obtuse-angled and right-angled situation does not provide this possibility, but that the acute situation naturally enhances the dynamism of the perspective view. Inspired by the achievements of the past and drawing on typologically diverse ways of shaping the corners of a building, the architect is able to achieve sufficient aesthetic effects to give a corner building the status of the sign or even the icon of a place. Apart from knowledge, there is also a need for skills and talent, without which even the most advantageous urban situation may turn against the professional reputation of the creator and, above all the quality of the urban space. 


\section{PRZYPISY}

1 T. Kozłowski, Tendencje ekspresjonistyczne $w$ architekturze współczesnej, Monografia 445, Politechnika Krakowska, Kraków 2013, s. 77.

2 M. Domińczak, A. Zaguła, Typologia kamienicy tódzkiej, Urząd Miasta Łodzi, Łódź 2016, s. 77.

${ }^{3}$ R. Krier, Town Spaces, Brikhäuser, Basel-Boston-Berlin 2006.

${ }^{4}$ L. Krier, Architektura wspólnoty, Terytoria, Gdańsk 2011.

${ }^{5}$ M. Domińczak, A. Zaguła, Typologia..., op. cit., 77-88.

6 P. Stalony-Dobrzański, Album domów narożnych miasta Krakowa - maszynopis wersji roboczej rozdziału rozprawy doktorskie pt. Dom narożny w bloku zabudowy miejskiej, wykonywanej na Wydziale Architektury Politechniki Krakowskiej, stan na 03.2019 r. Opracowanie udostepnione przez autora na potrzeby artykułu.

7 Z. Borycz, Forma architektoniczna narożnych budynków, w: Acta Scientarum Polonorum, Architectura 6 (4) 2007, s. 60, źród†o: http://www.architectura.actapol.net/pub/6_4_59.pdf (odsłona z dnia 25.03.2019)

8 T. Kozłowski, Tendencje..., op. cit., s.89.

\section{LITERATURA}

[1] Borycz Z., Forma architektoniczna narożnych budynków, w: Acta Scientarum Polonorum, Architectura 6 (4) 2007, s.59-70, źródło: http://www.architectura.actapol.net/pub/6 4 59.pdf lodsłona z dnia 25.03.2019)

[2] Domińczak M., Zaguła A., Typologia kamienicy łódzkiej, Urząd Miasta Łodzi, Łódź 2016.

[3] Kozłowski T., Tendencje ekspresjonistyczne w architekturze wspótczesnej, Monografia 445, Politechnika Krakowska, Kraków 2013.

[4] Krier L., Architektura wspólnoty, Terytoria, Gdańsk 2011.

5] Krier R., Town Spaces, Brikhäuser, Basel-Boston-Berlin 2006.

[6] Stalony-Dobrzański P. Album domów narożnych miasta Krakowa - maszynopis wersji roboczej rozdziału rozprawy doktorskiej pt. Dom narożny w bloku zabudowy miejskiej, wykonywanej na Wydziale Architektury Politechniki Krakowskiej, stan na 03.2019 r. Opracowanie udostepnione przez autora na potrzeby artykułu.

\section{ENDNOTES}

1 T. Kozłowski, Tendencje ekspresjonistyczne $w$ architekturze wspótczesnej (Expressionist Tendencies in Contemporary Architecture). Monograph 445, Cracow University of Technology, Cracow 2013, p. 77.

2 M. Domińczak, A. Zaguła, Typologia kamienicy łódzkiej (Typology of the Łódź Tenement House), Municipal Office in Łódź, Łódź 2016, p. 77.

${ }^{3}$ R. Krier, Town Spaces, Brikhäuser, Basel-Boston-Berlin 2006.

${ }^{4}$ L. Krier, Architektura wspólnoty, Terytoria, Gdańsk 2011.

${ }^{5}$ M. Domińczak, A. Zaguła, Typologia..., op. cit., pp. 77-88.

${ }^{6}$ Piotr Stalony-Dobrzański, Album domów narożnych miasta Krakowa (A)bum of Corner Houses in the City of Krakow) - a typescript of the working version of the chapter from the doctoral dissertation entitled Dom narożny w bloku zabudowy miejskiej, prepared at the Faculty of Architecture of Cracow University of Technology, as of 03.2019. The study made available by the author for the purposes of the paper.

7 Z. Borycz, Forma architektoniczna narożnych budynków, in: Acta Scientarum Polonorum, Architectura 6 (4) 2007, p. 60, retrieved at: http://www. architectura.actapol.net/pub/6 4 59.pdf (accessed: 25.03.2019).

8 T. Kozłowski, Tendencje..., op. cit., p. 89.

\section{BIBLIOGRAPHY}

[1] Borycz Z., Forma architektoniczna narożnych budynków, in: Acta Scientarum Polonorum, Architectura 6 (4) 2007, pp. 59-70, retrieved at: http:// www.architectura.actapol.net/pub/6 4 59.pdf (accessed: 25.03.2019).

[2] Domińczak M., Zaguła A., Typologia kamienicy tódzkiej, Urząd Miasta Łodzi, Łódź 2016.

[3] Kozłowski T., Tendencje ekspresjonistyczne $w$ architekturze współczesnej. Monograph 445, Politechnika Krakowska, Kraków 2013.

[4] Krier L., Architektura wspólnoty, Terytoria, Gdańsk 2011.

[5] Krier R., Town Spaces, Brikhäuser, Basel-Boston-Berlin 2006.

6] Stalony-Dobrzański P. Album domów narożnych miasta Krakowa - a typescript of the working version of the chapter from the doctoral dissertation entitled Dom narożny w bloku zabudowy miejskiej, prepared at the Faculty of Architecture of Cracow University of Technology, as of 03.2019. The study made available by the author for the purposes of the paper. 